\title{
TESTING HALAL LABELS, PRODUCT QUALITY, CELEBRITY ENDORSER AND REFERENCE GROUP OF WARDAH PURCHASE DECISIONS
}

\author{
Ginanjar Rahmawan'1) \\ Vita Putri Banwuati2) \\ 1) 2)Sekolah Tinggi Ilmu Ekonomi Surakarta, Jawa Tengah, Indonesia
}

\begin{abstract}
Abstrak
The increasingly fierce competition in the cosmetics industry requires companies to increase product excellence in order to compete. Wardah is a cosmetics that has the highest growth reaching $25 \%$. This research uses quantitative research methods using a questionnaire. The population in this study is Wardah Lipstick consumers in Solo. Samples taken in this study were 96 respondents with non probability sampling techniques, namely accidental sampling. This study aims to determine the effect of halal labels, product quality, celebrity endorsers and reference groups on purchasing decisions Wardah Lipstick. The data analysis technique used in this study is multiple linear regression analysis techniques processed with SPSS 16 applications. The results of this study are halal labels, product quality, celebrity endorsers and reference groups have a positive and significant effect on purchasing decisions Wardah Lipstick.
\end{abstract}

Keywords: halal label, product quality, celebrity endorser, reference group, purchase decision 


\section{INTRODUCTION}

Modern era like today, competition in the business world is getting tougher. One of the drivers of the growth of the cosmetics industry market is the beauty trend that has led to various types of beauty products for consumers. The increasingly fierce competition in the cosmetics industry requires companies to increase product excellence in order to compete. With the increasing number of competitors, the more choices of products that consumers can choose according to their needs. These consequences require consumers to be more careful in choosing products on the market.

Wardah is the cosmetics brand with the highest growth reaching 25\% in 2018. This growth is higher than the growth of the cosmetics industry alone which moves around 7\% (marketeers.com). In Solo there are Wardah Distributor Centers that market products in the Solo, Boyolali, Sukoharjo, Karanganyar, Sragen, Salatiga, Klaten, Wonogiri and Pacitan areas. Wardah Market Development said that the largest Wardah Lipstick market share was in the Solo area by $40 \%$, while in Boyolali $6 \%$, Sukoharjo $10 \%$, Karanganyar 5\%, Sragen 5\%, Salatiga 10\%, Klaten $8 \%$, and the remaining $15 \%$ were divided in Wonogiri and Pacitan. In Solo, there is Wardah Beauty House which sells all kinds of Wardah products.

An improved understanding of religion makes consumers have a high awareness in choosing beauty products. Especially for Muslim women who feel more confident if the cosmetic products already have halal certification. Cosmetics have a risk of use that needs to be considered given the chemical content contained in the product. As a guarantee of the quality of the products produced, Wardah received a CPKB (Good Cosmetics Manufacturing) certificate in 2006.

Wardah first won the Top Brand Award in 2014 in the lipstick category. Based on data from the Top Brand Index from 2017 to 2019 Wardah lipstick category occupies the TOP title for three years in a row. Of course it is an achievement that is not easy to obtain given the number of similar cosmetic products sold in the market. Wardah Lipstick products in the TOP category signify that the products are popular with consumers, which shows the popularity of these products that support purchasing decisions. 


\section{LITERATURE REVIEW}

a. Halal Labe

Utami (2013) argues that the halal label is the inclusion of written or halal statements on the packaging of a product to show that the product is a halal product. According to Utami (2013) there are 4 indicators of Halal Label namely Pictures, Writing, Combination of images and writing, and Sticking to the packaging.

b. Product quality

Product quality according to Kotler and Armstrong (2012) is a characteristic of a product or service that supports its ability to satisfy consumers. According to Tjiptono (1997), there are 6 dimensions of product quality that need attention: performance, features, reliability, durability, conformity to specifications, and aesthetics.

c. Celebrity endorsers

Whereas Shimp (2003) argues that celebrity endorsers are the use of artists as advertising stars in print, social media and television media. Royan (2004) said that there are 4 indicators of Celebrity endorsers with the VisCAP model, namely: Visibility, Credibility, Attraction, and Power.

d. Reference Group

The reference group according to Sumarwan (2011) is an individual or group that significantly influences a person's behavior. According to Jalasena (2013) the Reference Group can be measured by indicators namely reference group knowledge about the product, the credibility of the reference group, the experience of the reference group, the activeness of the reference group, and the attractiveness of the reference group.

e. Buying decision

Purchasing decision according to Kotler \& Keller (2009) is a stage of consumers who already have a choice and are ready to make a purchase transaction or pay with ownership rights or use of an item or service. According to Kotler and Keller (2009) the stages of purchasing decision making consist of five stages namely problem 
recognition, information search, alternative evaluation, purchasing decisions and post-purchase behavior.

Hypothesis:

H1: Halal label has a positive effect on the decision to purchase Wardah Lipstick in Solo.

H2: Product Quality has a positive effect on the Purchasing Decision of Wardah Lipstick in Solo.

H3: Celebrity Endorser has a positive influence on Wardah's Lipstick Purchasing Decision in Solo.

H4: Reference group has positive influence on the decision to purchase Wardah Lipstick in Solo

\section{RESEARCH METHOD}

The type of data used in this study is quantitative data. This study takes Wardah Lipstick Consumer population in Solo. The sampling technique in this study with non probability sampling is accidental sampling. Data collection methods in this study used a questionnaire that was distributed to 96 respondents. The data analysis technique used in this study is multiple linear regression analysis processed with the application of SPSS 16.

\section{RESULTS}

a. Test Instrument

The instrument test consists of validity and reliability tests. In the validity test, the multiple regression model is declared valid because it has a calculated $r$ value greater than $r$ table (0.1689). In the reliability test, the Cronbach alpha results show values above 0.60 so it is said to be reliable.

b. Classic assumption test

The classic assumption test consists of a normality test, a multicollinearity test and a heteroscedasticity test. In the normality test, the multiple regression model fulfills the normality assumption because the sig (2-tailed) value $\geq 0.05$. In the multicollinearity test, the toll value $>0.10$ and the VIF value of all variables $<10$. In 
the heteroscedasticity test, a value of sig $\geq 0.05$ so that no heteroscedasticity was declared.

c. Multiple Regression Analysis

Based on the calculation results obtained as follows:

$$
\mathrm{Y}=-3,174+0,549 \mathrm{X} 1+0,159 \mathrm{X} 2+0,239 \mathrm{X} 3+0,330 \mathrm{X} 4+\mathrm{e}
$$

A constant of $-3,174$ means that if the purchasing decision level $(Y)$ without the influence of the Halal Label, Product Quality, Celebrity Endorser and Reference Group variables will be negative or the purchase decision will decrease. The halal label regression coefficient is 0.549 which means that if every increase or increase in the halal label variable is positive, the purchasing decision will also increase by $54.9 \%$. Product quality regression coefficient of 0.159 which means that if each increase or increase in the product quality variable is positive, the purchasing decision also increased by $15.9 \%$. Celebrity endorser regression coefficient of 0.239 , which means that if every increase or increase in the Celebrity endorser variable is positive then the purchasing decision also increased by $23.9 \%$. The reference group regression coefficient is 0.330 which means that if each increase or increase in the reference group variable is positive, the purchasing decision will also increase by $33 \%$.

d. T test

Based on the results of the $t$ test it can be seen that the sig value of the halal label variable is 0,000 , the quality of the product is 0.005 , the celebrity endorser is 0.008 and the reference group is 0,000 , which is overall $<0.05$ so that it has an influence on the purchasing decision of wardah lipstick individually.

e. Test $\mathrm{R}^{2}$ (coefficient of determination)

Based on the calculation results, the detremination coefficient value of 0.856 means that the independent variables in the model (Halal Label, Product Quality, Celebrity Endorser, Reference Group) explain the variation of Wardah Lipstick Purchasing Decision in Solo by $85.6 \%$. 


\section{DISCUSSION}

a. Effect of Halal Labels on Purchasing Decisions

The results showed that the Halal Label had a positive and significant effect on Purchasing Decisions on Wardah Lipstick consumers in Solo. Based on these results, this study succeeded in proving the first hypothesis which states that Halal Label has a positive and significant effect on Purchasing Decisions. The existence of Halal Labels on products is very important considering the awareness of consumers who are more confident in using halal-certified products. The results of this study are in accordance with research conducted by Premi Wahyu Widyaningrum (2018).

b. Effect of Product Quality on Purchasing Decisions.

The results of this study indicate that Product Quality has a positive and significant effect on Purchasing Decisions on Wardah Lipstick consumers in Solo. Product Quality Variable has an individual role in supporting the improvement of Wardah Lipstick purchasing decisions in Solo. Based on these results, the results of this study prove the second hypothesis which states Product Quality has a positive and significant effect on Purchasing Decisions. The quality of lipstick products which includes comfortable and safe to use, the content that keeps the lips moist and makes bright lips influence consumers to use Wardah lipstick. The results of this study are consistent with research conducted by Ipa Audina Br Harahap and Wahyu Hidayat (2017)

c. Effect of Celebrity Endorser on Purchasing Decisions

The results of this study indicate that Celebrity Endorser has a positive and significant effect on purchasing decisions on Wardah Lipstick consumers in Solo. Based on these results, the results of this study prove the third hypothesis which states that Celebrity Endorser has a positive and significant effect on purchasing decisions. Famous celebrity endorsers have charisma, positive appeal and inspire someone to the product being promoted. The results of this study are in accordance with research conducted by Kadek Ayu Dwi Sudias Kumala Sukma (2018),

d. Effect of Reference Groups on Purchasing Decisions.

The results of this study indicate that the Reference Group has a positive and significant effect on Purchasing Decisions on Wardah Lipstick consumers in Solo. 
Based on these results, the results of this study prove the fourth hypothesis which states the Reference Group has a positive and significant effect on Purchasing Decisions. Someone who will choose a product will ask for opinions from others who already have experience. The results of this study are consistent with research conducted by Riski Yuliana Pramudi (2015)

\section{CONCLUSIONS}

Based on the results of the halal label research, product quality, celebrity endorsers and reference groups have a positive and significant effect on purchasing decisions on Wardah Lipstick in Solo. Based on the conclusions and discussion obtained from the results of the study, the suggestions that can be recommended for the next research consideration is to be able to develop research using variables outside this research such as Halal Labels, Product Quality, Celebrity Endorsers and Reference Groups. In addition, further research can also develop research by taking populations in other regions.

\section{REFERENCES}

Anoraga, Bintang Jalasena dan Sri Setyo Iriani, (2013), Pengaruh Gaya Hidup dan Kelompok Acuan Terhadap Keputusan Pembelian Smartphone Samsung Galaxy, Jurnal Ilmu Manajemen, Vol. 1, No. 4.

Harahap, I.A., dan Wahyu Hidayat, (2017), Pengaruh Kualitas Produk Dan Harga Terhadap Keputusan pembelian Masker Wajah Mustika Ratu (Studi Kasus pada Konsumen Kec. Tembalang Kota Semarang). Jurnal. Semarang : Fakultas Ilmu Sosial dan Politik Universitas Diponegoro.

Kotler, Philip and Gary Amstrong. (2012), Prinsip-prinsip Pemasaran, Edisi 13, Jilid 1. Jakarta : Erlangga.

Kotler, Philip dan Kevin Lane Keller, (2009), Manajemen Pemasaran. Jakarta : PT. Indeks. Pramudi Riski.Y., (2015) Pengaruh Gaya Hidup Konsumtif dan Kelompok Referensi Terhadap Keputusan Pembelian Kosmetik Lokal, Jurnal Riset Ekonomi dan Manajemen, Vol. 15, No. 2, Hal. 280-301.

Royan, Frans M, (2004), Marketing Celebrities. Jakarta : PT Elex Media Komputindo.

Shimp, Terence, (2003), Periklanan Promosi \& Aspek Tambahan Komunikasi. Pemasaran. Terpadu, Jilid 1 (edisi 5) , Jakarta : Erlangga.

Sukma, K.A., I Ketut Nurcahya dan Alit Suryani, (2016), Pengaruh Celebrity Endorser, Brand Image dan Kepercayaan Terhadap Keputusan Pembelian Produk Pembersih Wajah Men's Biore, E-Jurnal Manajemen Unud, Vol. 5, No. , hal. 4016-4043.

Sumarwan, Ujang, (2010), Perilaku Konsumen: Teori dan penerapan dalam pemasaran, Bogor : Ghalia Indonesia. 
Tjiptono, Fandy, (1997), Strategi Pemasaran, Yogyakarta : Andi.

Utami, dan Wahyu Budi, (2013), Pengaruh Label Halal Terhadap Keputusan Pembelian (Survei Pada Pembeli Produk Kosmetik wardah di Outlet Wardah Griya Muslim An-Nisa Yogyakarta). Skripsi. Yogyakarta: Fakultas Ilmu Sosial dan Humaniora UIN Sunan Kalijaga.

Widyaningrum, P.W., (2018), Pengaruh Label Halal, Asosiasi Merek, Iklan, dan

Celebrity Endorser terhadap Keputusan Pembelian (Survei Pada Konsumen Wardah Di Malang), Jurnal Capital, Vol. 1, No. 2.

www.marketeers.com, diakses kamis, 5-12-2019

www.topbrandaward.com, diakses kamis, 5-12-2019 